\title{
Natalizumab-induced hyporegenerative anaemia and leukopenia: a case report
}

\author{
Salman Mansoor ${ }^{*}$ (D), Siobhan Kelly, Aine Burke, Mohammad Hijaz Adenan, Eimear Joyce, Aine Waters, \\ Grainne McPartland and Kevin Murphy
}

\section{Background}

Natalizumab (Nz), a monoclonal antibody has been in medicinal use for the treatment of relapsing-remitting multiple sclerosis (RRMS) since 2004 [1].

Haematological complications which are associated with its long-term use have been reported [2-4]. Animal studies have shown conflicting evidence of some reporting haematological complications [5-8], though some did not show such an observation [9].

There are rare reports of immune-mediated hemolysis and thrombocytopenia associated with Natalizumab [2,3].

Reversible hyporegenerative anaemia secondary to Natalizumab has been described [4], but associated leucopenia to the best of our knowledge is not described in the literature.

Our case highlights the risk of non-immune-mediated reversible hyporegenerative anaemia co-occurring with leucopenia and lymphopenia which to date has not been reported.

\section{Case}

We report a case of a 21-year old student with relapsingremitting multiple sclerosis (RRMS). He was diagnosed at the age of 12 years and was on Natalizumab.
Past disease-modifying treatment included injection interferon beta 1a $44 \mathrm{mcg}$ subcutaneous 3 times/week for 4 years. This was switched to Natalizumab 5 years ago in 2014 due to high disease activity.

Since being on Natalizumab, he achieved disease remission. However, it was first noticed that his haemoglobin and white cells count were decreasing in November 2018 which prompted further investigations.

Baseline haemoglobin between July 2016 and 2017 was between 14 and $16 \mathrm{~g} / \mathrm{dL}$-which dropped sequentially to ranges from 8 to $10 \mathrm{~g} / \mathrm{dL}$ from 2018 to 2019 , as shown in Fig. 1.

The white cell count also dropped during the same period he was on Natalizumab from 6.5 to $1.42 \times$ $10^{9} /$ L. Lymphocyte count progressively dropped to $0.11 \times 10^{9} / \mathrm{L}$. Trends are shown in Figs. 2 and 3 respectively.

The platelet counts stayed stable throughout the time period. He was investigated extensively for this drop in his blood lines and the notable abnormalities were evidence of non-immune haemolysis, splenomegaly and hyperbilirubinemia.

The rest of his haematological parameters are shown in Table 1.

\footnotetext{
* Correspondence: salmanmansoor.dr@gmail.com

Sligo University Hospital, Sligo, Ireland
} 


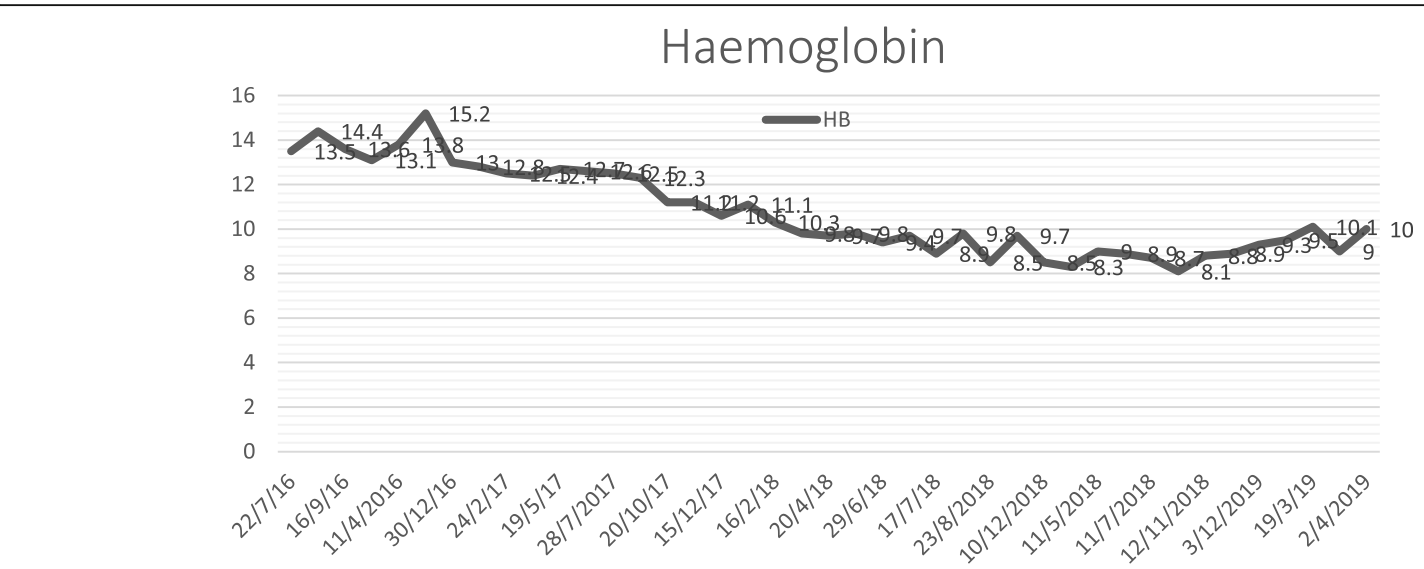

Fig. 1 Haemoglobin levels on Natalizumab which was stopped on 12/11/2018

Bone marrow aspirate and trephine showed erythrodysplasia. Genetic panel and karyotyping were negative for acquired genetic changes for myelodysplasia.

Genetic panel also included inherited bone marrow failure disorders (congenital dyserythroblastic anaemia, congenital bone marrow failure, Diamond-Blackfan anaemia) which were negative. Blood lymphocyte subset analysis revealed preserved B-cells and depletion of $\mathrm{T}$ and NK cells.

Non-immune hemolysis has been confirmed by repeatedly negative direct Coombs test (DCT), raised LDH, absent haptoglobin and raised bilirubin, notably urinary hemosiderin was negative with a poor reticulocyte response despite anaemia. Pertinent negative investigations included screening for haemoglobinopathies, paroxysmal nocturnal haemoglobinuria, G6PD deficiency, and parvovirus B19 infections.
Natalizumab was stopped in November 2018 after a total of 44 infusions. His blood lines started showing improvements which were suggestive of Natalizumabassociated reversible hyporegenerative anaemia with leucopenia. Due to a sensory relapse in March 2019, he has been started on glatiramer acetate $40 \mathrm{mg} \mathrm{S/C}$ injection via Autoject device 3 days/week which he is tolerating well, and his cell counts are improving.

\section{Discussion}

Hyporegenerative anaemia is defined as a reticulocyte count of $<50 \times 10^{9} /$ L. [10] Hyporegenerative anaemia is further classified by World Health Organization (WHO) into aplastic anaemia, pure red cell aplasia, myelodysplastic syndrome, deficiency states (iron deficiency/vitamins), marrow infiltration/fibrosis, anaemia of chronic disease and erythropoietin underproduction

\section{White cell count}

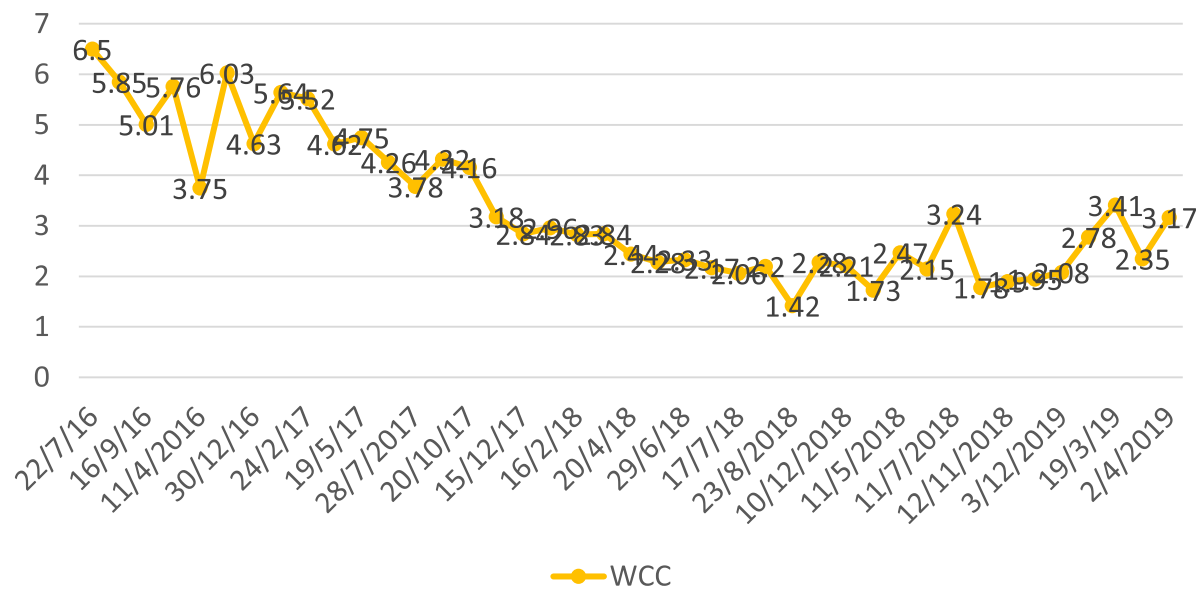

Fig. 2 White cell counts on Natalizumab which was stopped on 12/11/2018 


\section{Lymphocytes}

2.5

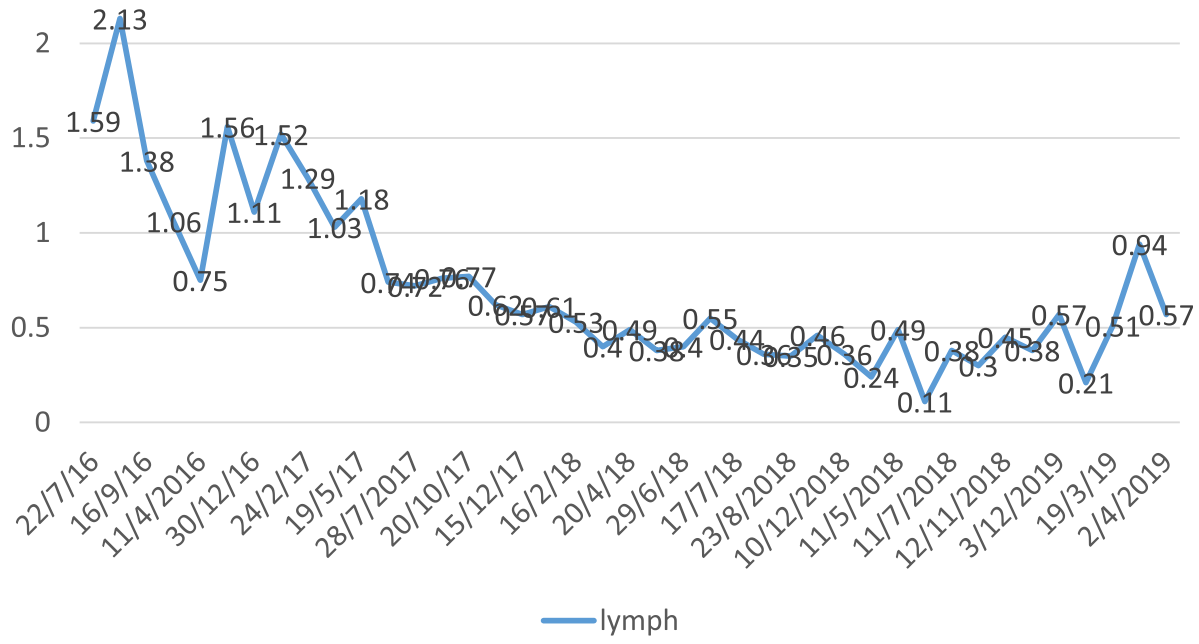

Fig. 3 Lymphocyte count on Natalizumab which was stopped on 12/11/2018

[10]. In our case, the possibilities included anaemia of chronic disease but myelodysplastic syndrome could still be a differential although his genetic tests were normal. A previously proposed mechanism for the development of anaemia due to Natalizumab maybe owing to the target site $\alpha 4 \beta 1$ on bone marrow cells which blocks erythrocyte maturation [4]. To the best of our knowledge, there has not been a previous case report which describes the co-existence of lymphopenia with Natalizumab and the underlying mechanism for this remains unknown.

\section{Conclusion}

The association, in this case, is still uncertain. Reversible hypogenerative anaemia secondary to Natalizumab has been described, but associated leucopenia is not previously reported.

Table 1 Haematological parameters in November 2018

\begin{tabular}{lll}
\hline Blood parameters & Result & Reference value \\
\hline Reticulocyte count & $2.1 \%$ & $0.5 \%$ to $2.5 \%$ \\
Absolute retic count & 65 & $35.2-122.8$ \\
RBC's & $3.15 \times 10^{12} / \mathrm{L}$ & $4.50-6.50 \times 10^{12} / \mathrm{L}$ \\
Erythropoietin levels & 211 & \\
Haptoglobin & $<0.243 \times \mathrm{g} / \mathrm{L}$ & $0.45-2.05 \times \mathrm{g} / \mathrm{L}$ \\
MCV & $80.4 \mathrm{fl}$ & $78-98 \mathrm{fl}$ \\
Basophils & $0.4 \times 10^{9} / \mathrm{L}$ & $0.00-0.10 \times 10^{9} / \mathrm{L}$ \\
Eosinophils & $0.2 \times 10^{9} / \mathrm{L}$ & $0.02-0.5 \times 10^{9} / \mathrm{L}$ \\
Monocytes & $0.15 \times 10^{9} / \mathrm{L}$ & $0.2-1.0 \times 10^{9} / \mathrm{L}$ \\
\hline
\end{tabular}

Acknowledgements

Not applicable.

\section{Authors' contributions}

$S M, S K, A B$, and $K M$ were involved in the writing of manuscript diagnosing and treating the patient. MHA, EJ, GM, and AW helped in the manuscript writing and compiling the data for this case. All authors read and approved the final manuscript.

\section{Consent for publication}

Patient was informed and written consent taken from the patient for this publication. Animal subjects: all authors have confirmed that this study did not involve animal subjects or tissue.

\section{Competing interests}

In compliance with the ICMJE uniform disclosure form, all authors declare the following: Payment/services info: all authors have declared that no financial support was received from any organization for the submitted work. Financial relationships: all authors have declared that they have no financial relationships at present or within the previous three years with any organizations that might have an interest in the submitted work. Other relationships: all authors have declared that there are no other relationships or activities that could appear to have influenced the submitted work. The authors declare that they have no competing interests.

Received: 15 July 2019 Accepted: 23 December 2019

Published online: 09 January 2020

\section{References}

1. Tysabri Approved for Multiple Sclerosis https://www.drugs.com/newdrugs/ tysabri-approved-multiple-sclerosis-162.html

2. Maidaglia $L$, Rodriguez Ruiz $M$, et al. Severe haematological complications during treatment with natalizumab. Mult Scler J. 2012;18(11):1644-6.

3. Stosic M, De Jesus P, McCarthy J, et al. Immune thrombocytopenic purpura in a patient with multiple sclerosis treated with natalizumab. Neurology. 2011;77:505-7.

4. Monteleone F, Buccisano F, et al. Reversible hyporegenerative anemia during natalizumab treatment. Mult Scler. 2014;21(2):257-8.

5. Biogen. Tysabri (natalizumab) injection, for intravenous use US prescribing information. 2015. http://www.tysabri.com/prescribinglnfo 
6. Wehner NG, Shopp G, Oneda S, Clarke J. Embryo/fetal development in cynomolgus monkeys exposed to natalizumab, an alpha4 integrin inhibitor. Birth Defects Res B Dev Reprod Toxicol. 2009;86(2):117-30.

7. Wehner NG, Shopp G, Osterburg I, Fuchs A, Buse E, Clarke J. Postnatal development in cynomolgus monkeys following prenatal exposure to natalizumab, an alpha4 integrin inhibitor. Birth Defects Res B Dev Reprod Toxicol. 2009;86(2):144-56.

8. Houtchens MK, Kolb CM. Multiple sclerosis and pregnancy: therapeutic considerations. J Neurol. 2013;260(5):1202-14.

9. Wehner NG, Shopp G, Rocca MS, Clarke J. Effects of natalizumab, an alpha4 integrin inhibitor, on the development of Hartley guinea pigs. Birth Defects Res B Dev Reprod Toxicol. 2009;86(2):98-107.

10. European School of Haematology, Esh.org http://www.esh.org/files/doc/ IRON2009_CAP.4\%28108-141\%29.pdf

\section{Publisher's Note}

Springer Nature remains neutral with regard to jurisdictional claims in published maps and institutional affiliations.

\section{Submit your manuscript to a SpringerOpen ${ }^{\circ}$ journal and benefit from:}

- Convenient online submission

- Rigorous peer review

- Open access: articles freely available online

- High visibility within the field

- Retaining the copyright to your article

Submit your next manuscript at $\boldsymbol{\nabla}$ springeropen.com 